\title{
Supplementary data-2
}

\section{Suzuki-Miyaura Reactions of Arenediazonium Salts Catalyzed by Pd(0)/C. One- Pot Chemoselective Double Cross-Coupling Reactions}

\author{
Rachel Taylor and François-Xavier Felpin* \\ Université Bordeaux 1; CNRS; Institut des Sciences Moléculaires, 351 Cours de la Libération, Talence, F-33405 France \\ * Corresponding author, Email address: fx.felpin@ism.u-bordeauxl.fr
}

\section{Contents}

General Methods

Preparation of compounds 


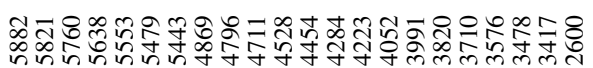

201111110
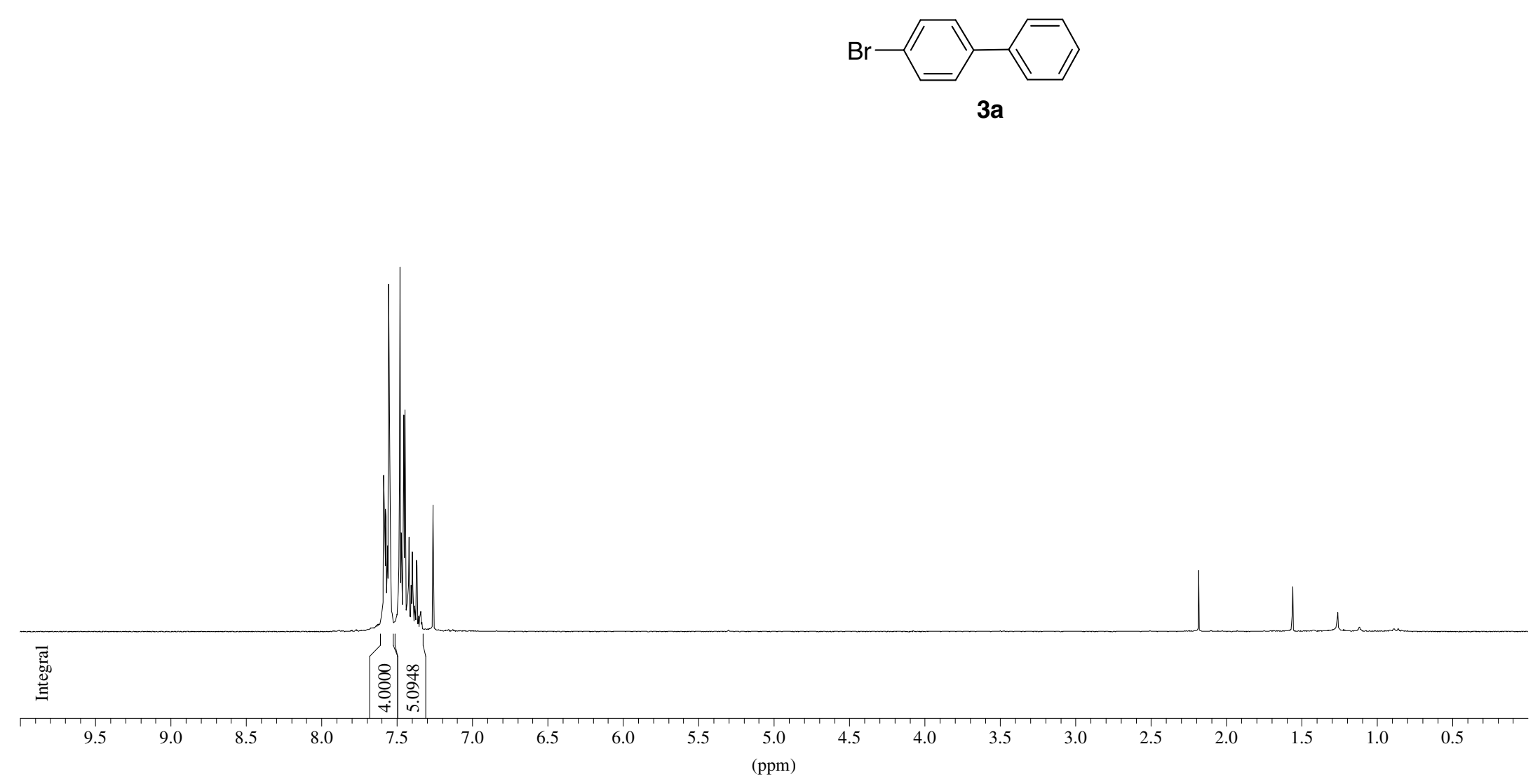


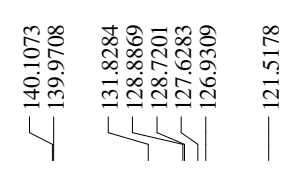

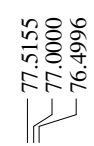

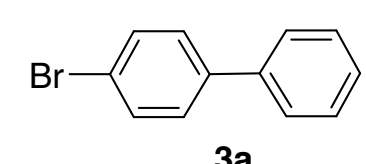

$3 a$

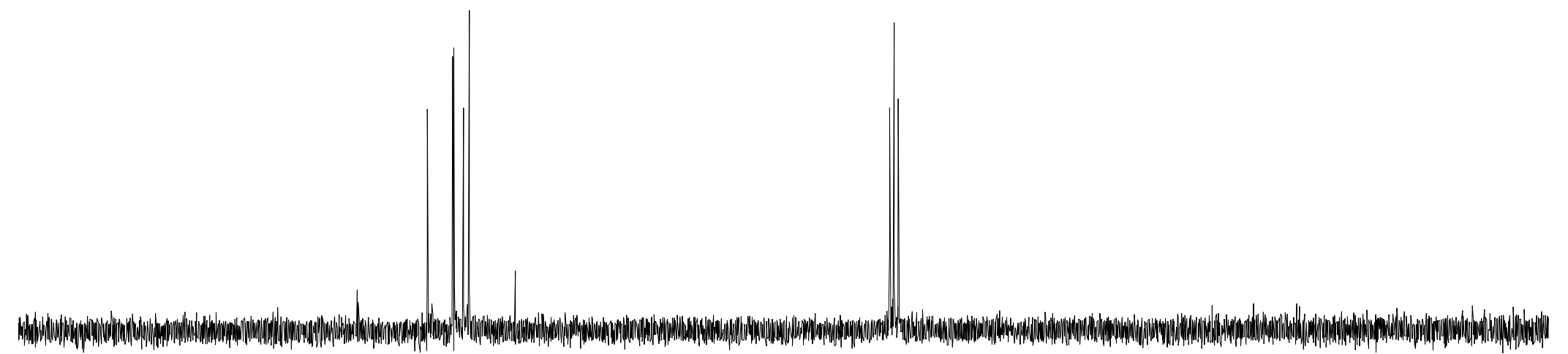




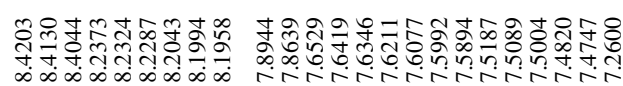

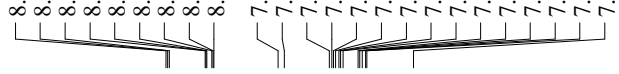
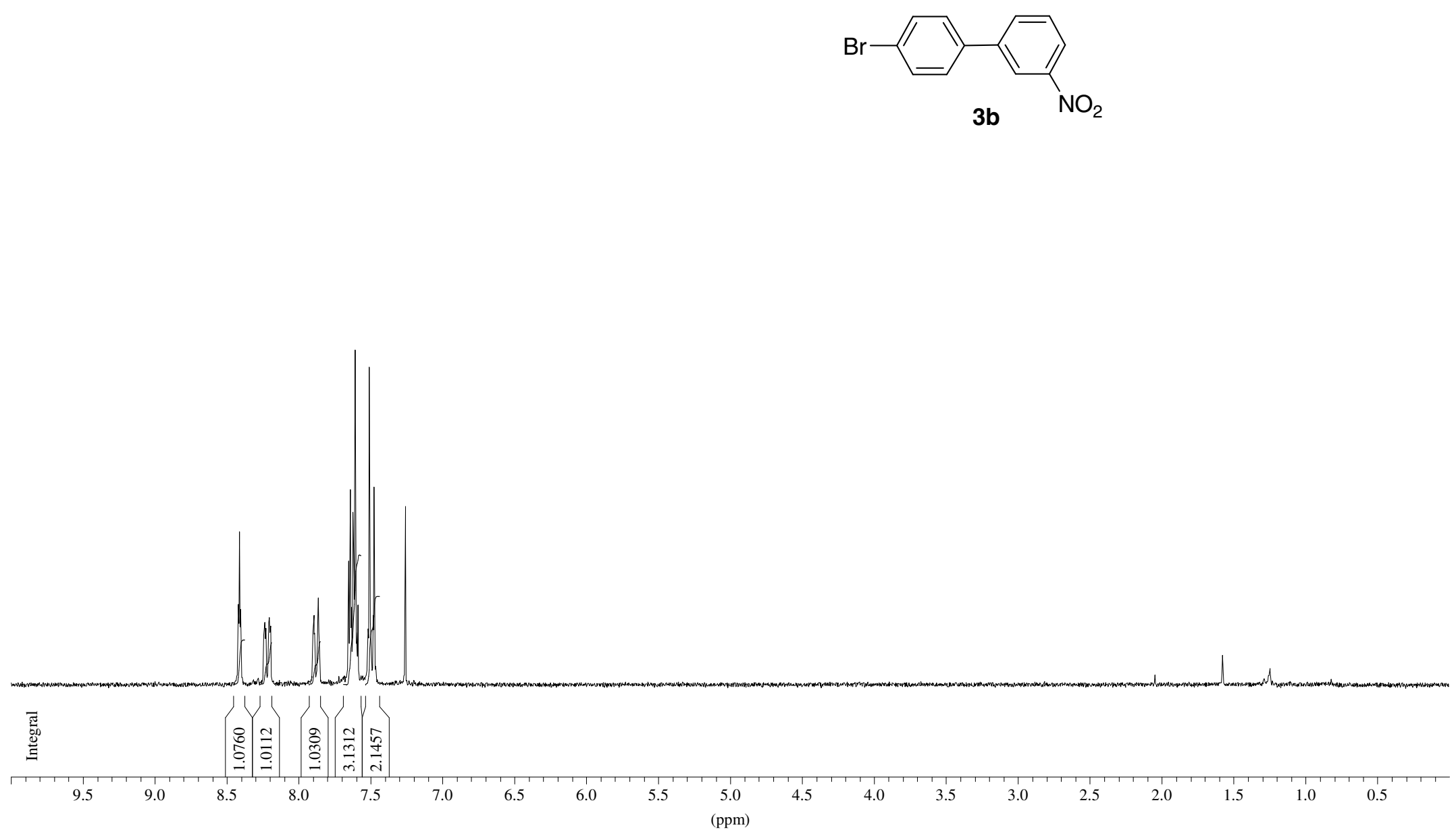

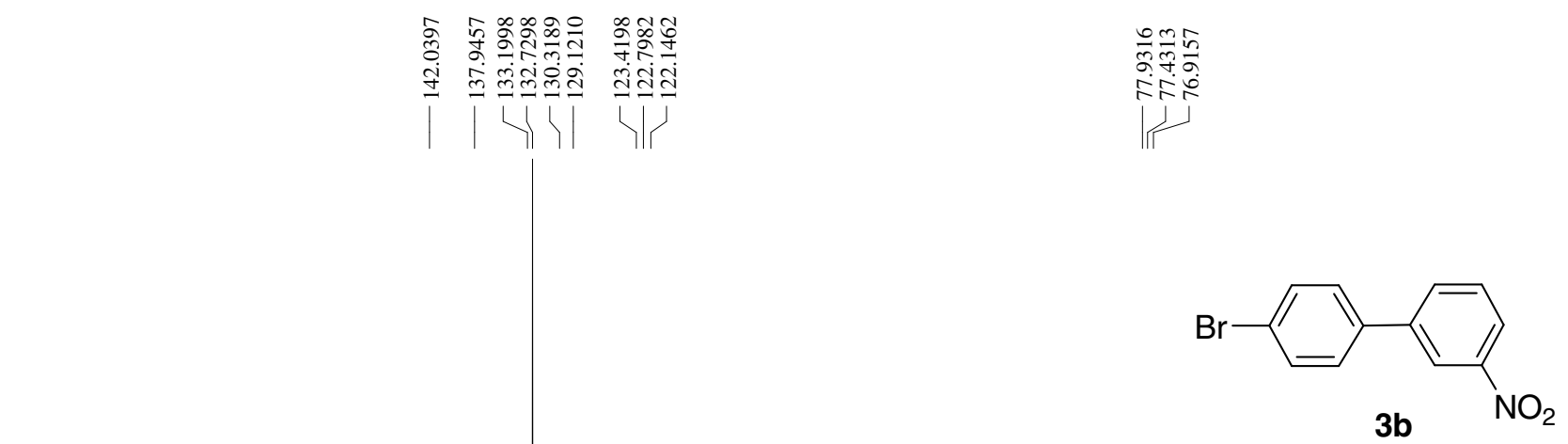

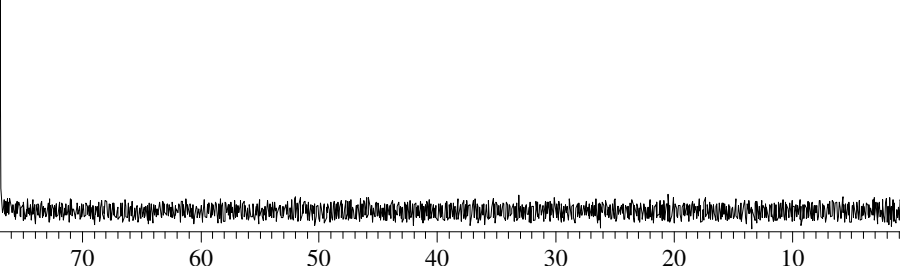




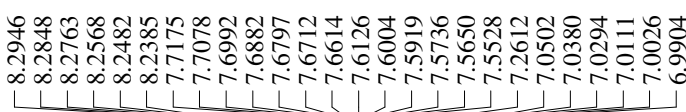
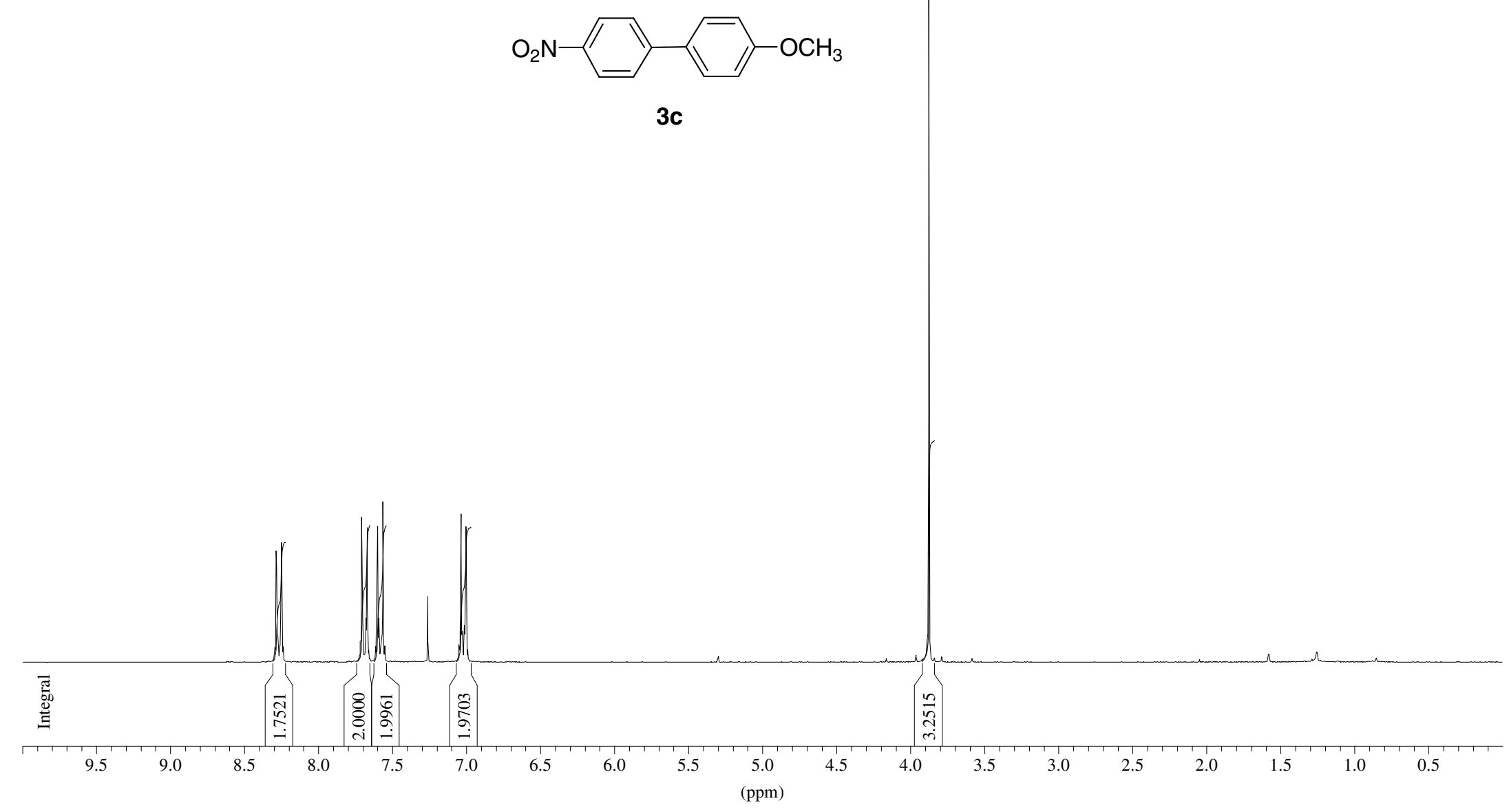


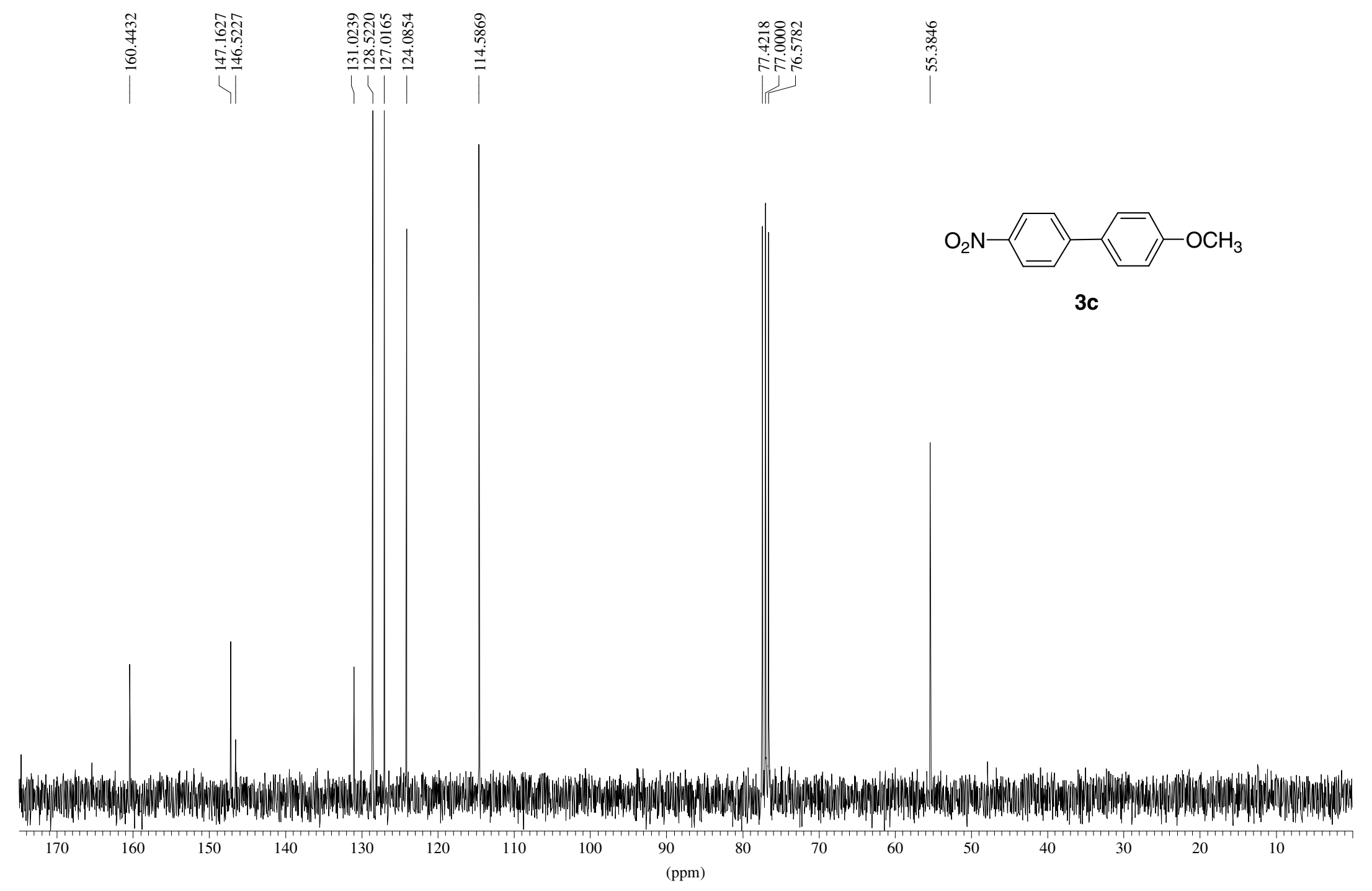




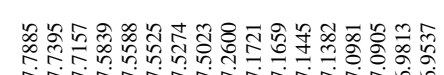

Lisisisisiso

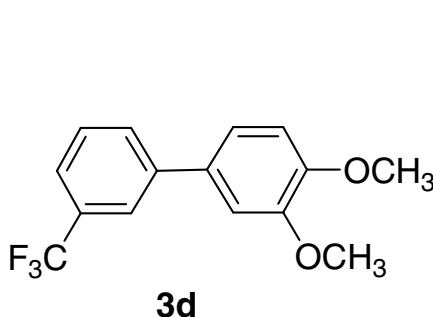

$3 d$

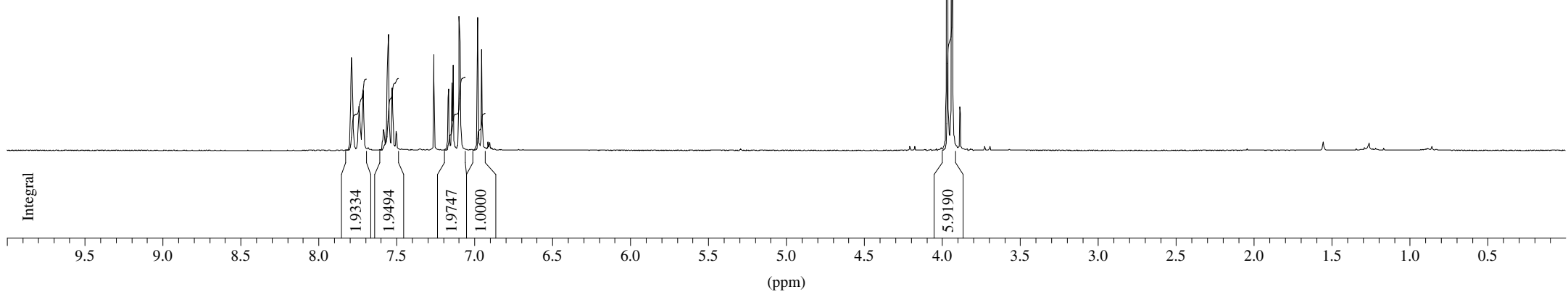



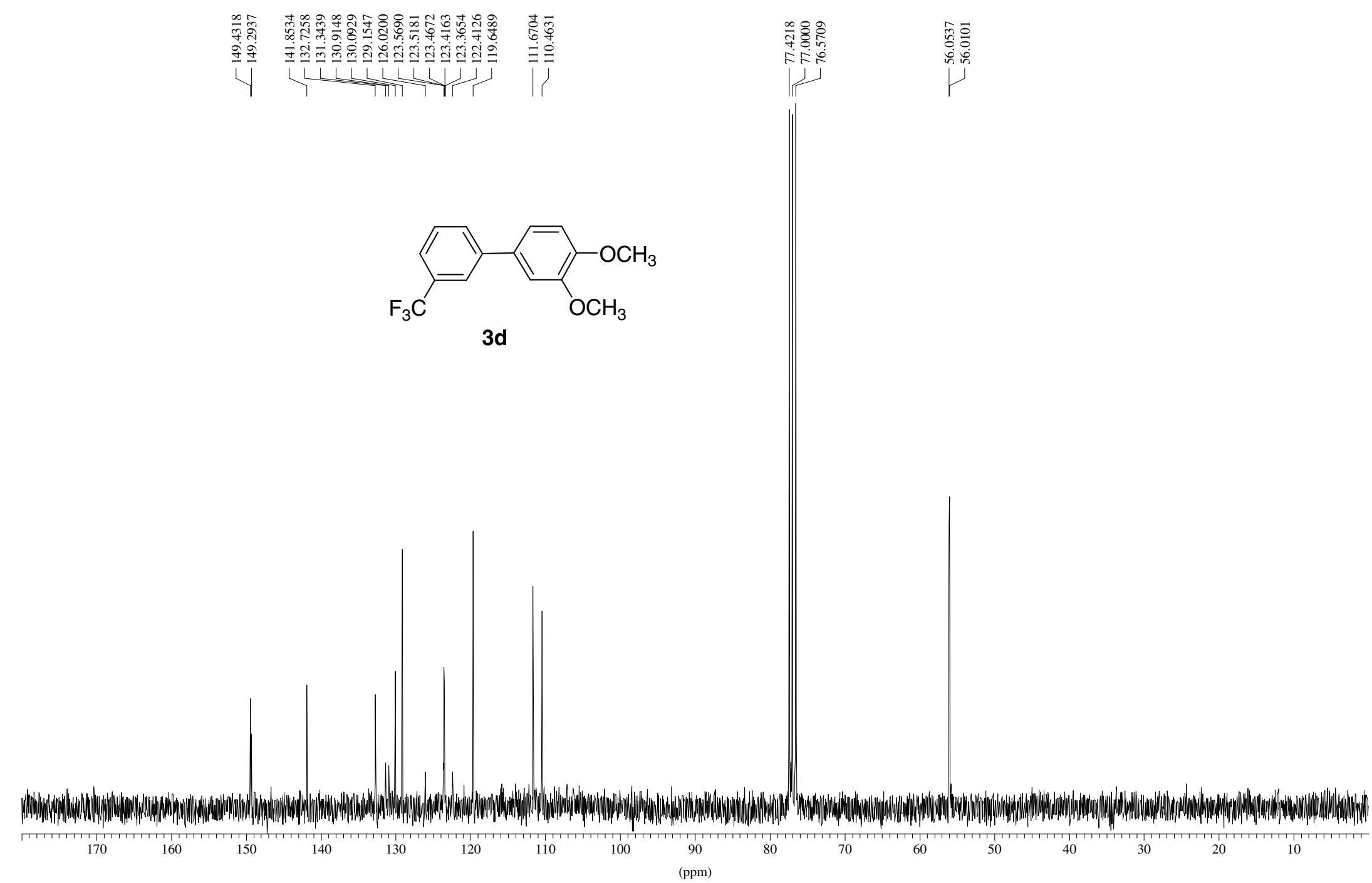


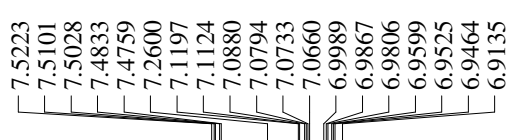

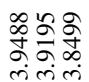

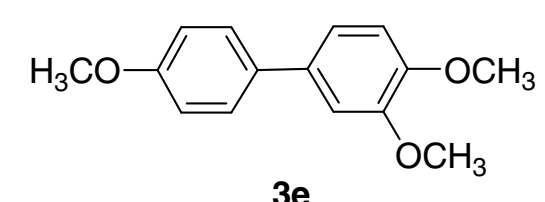

$3 e$

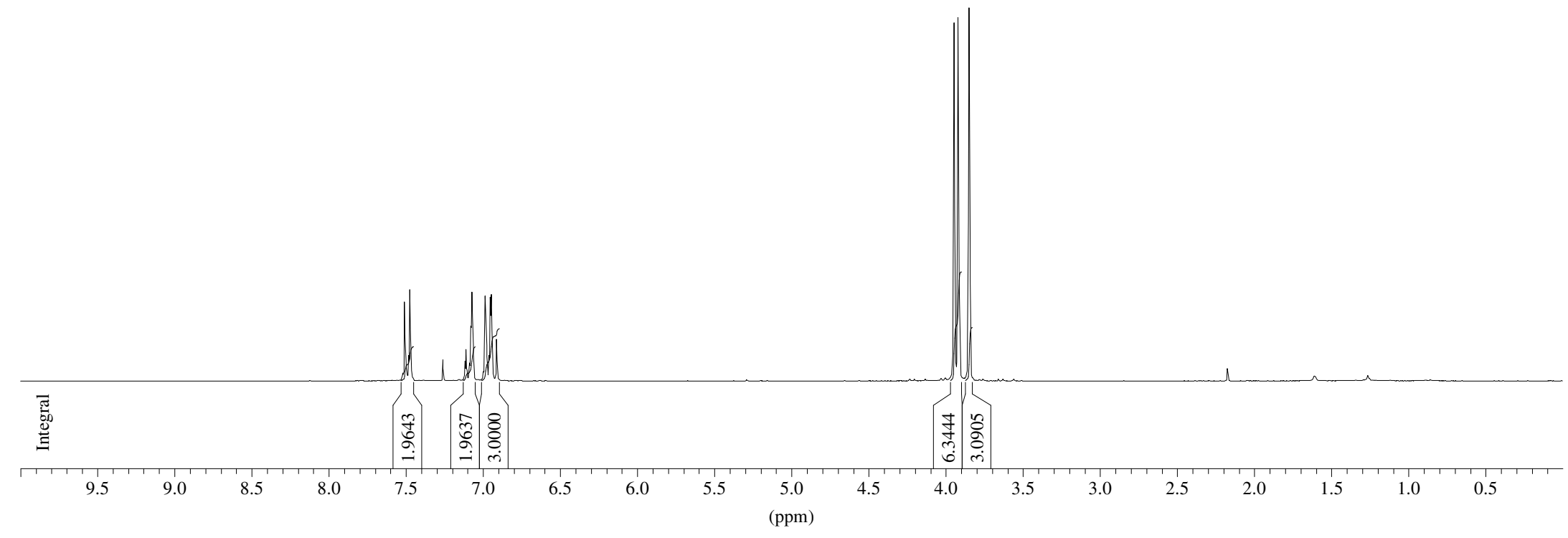




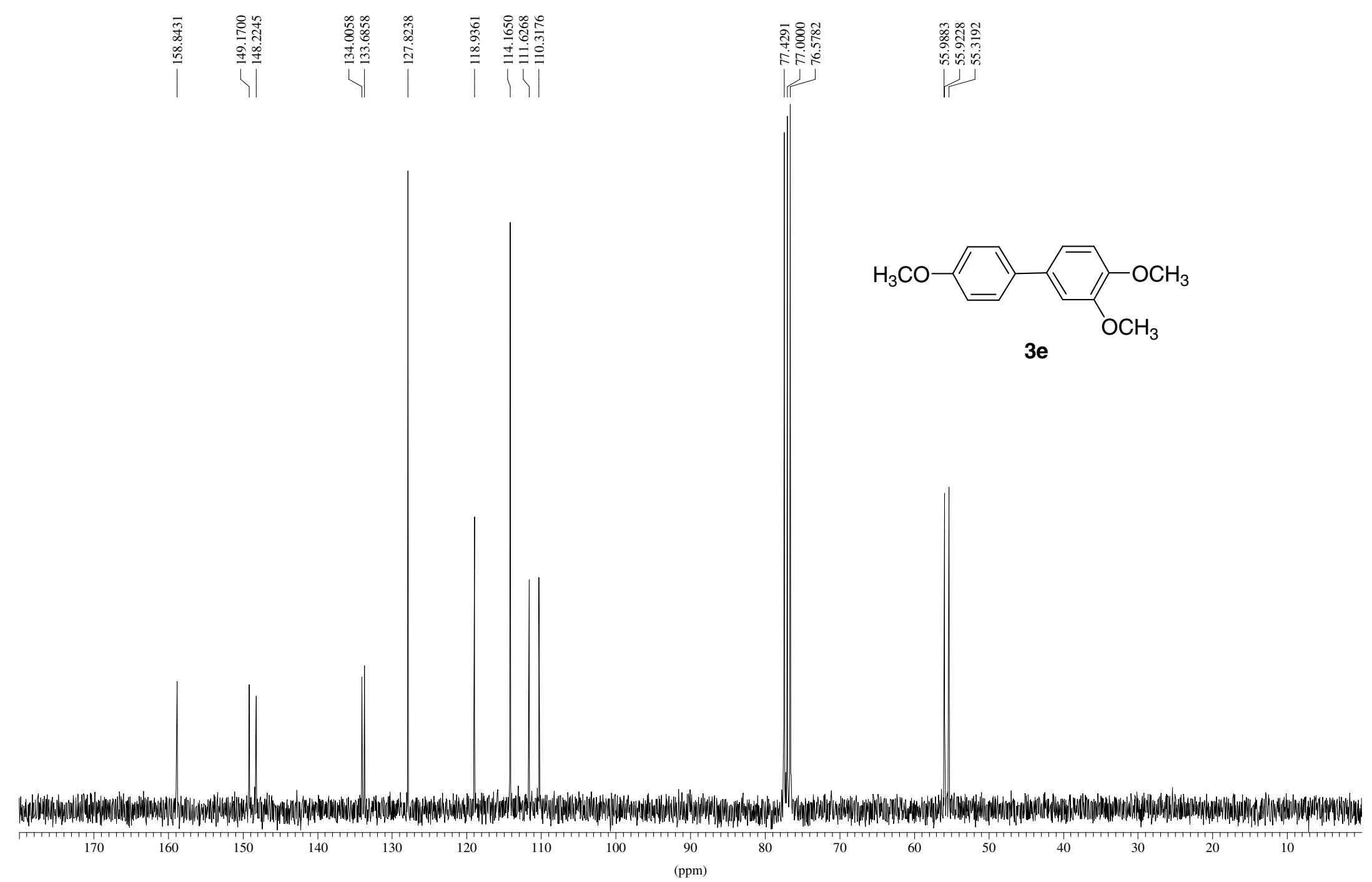




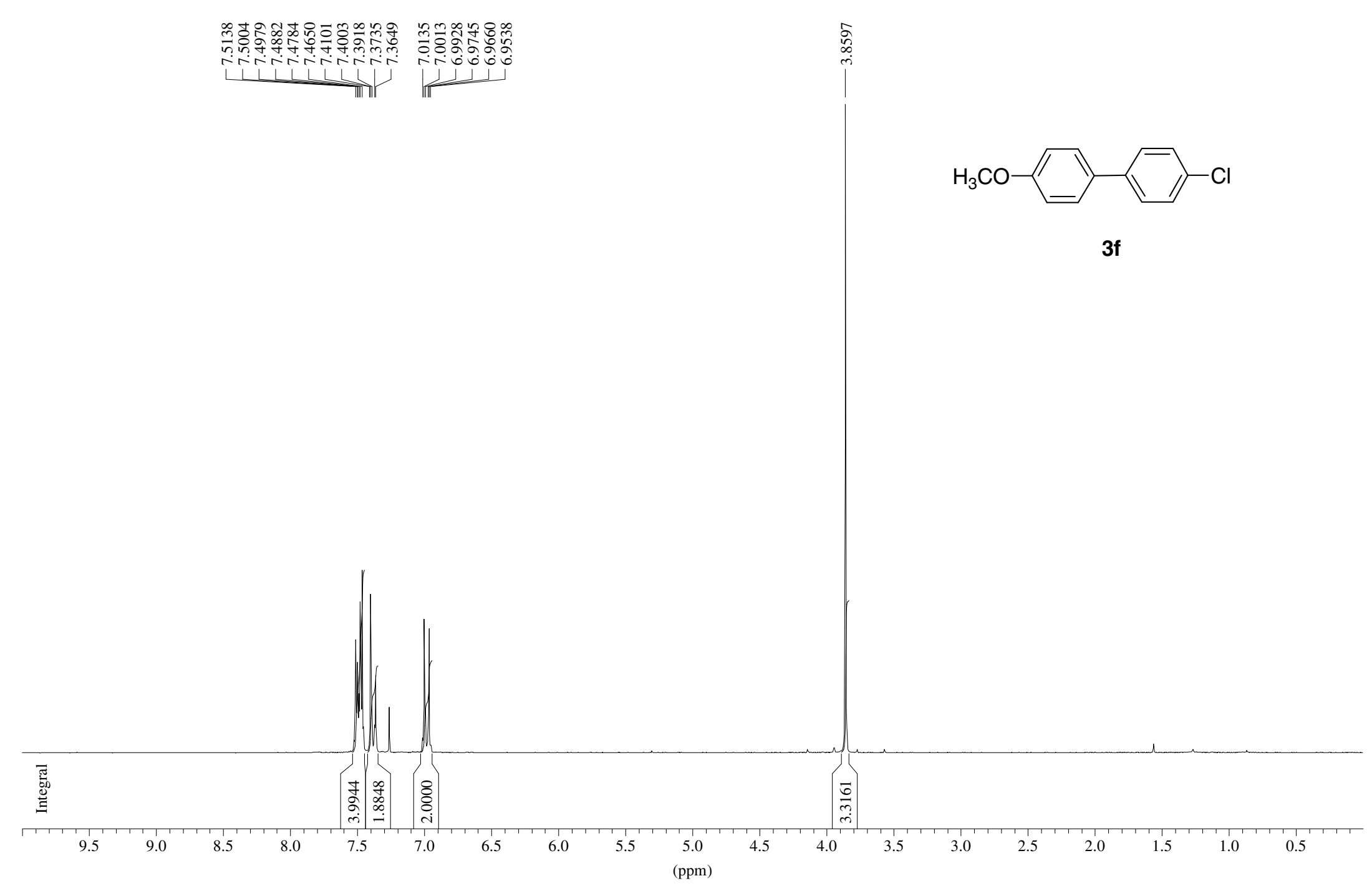



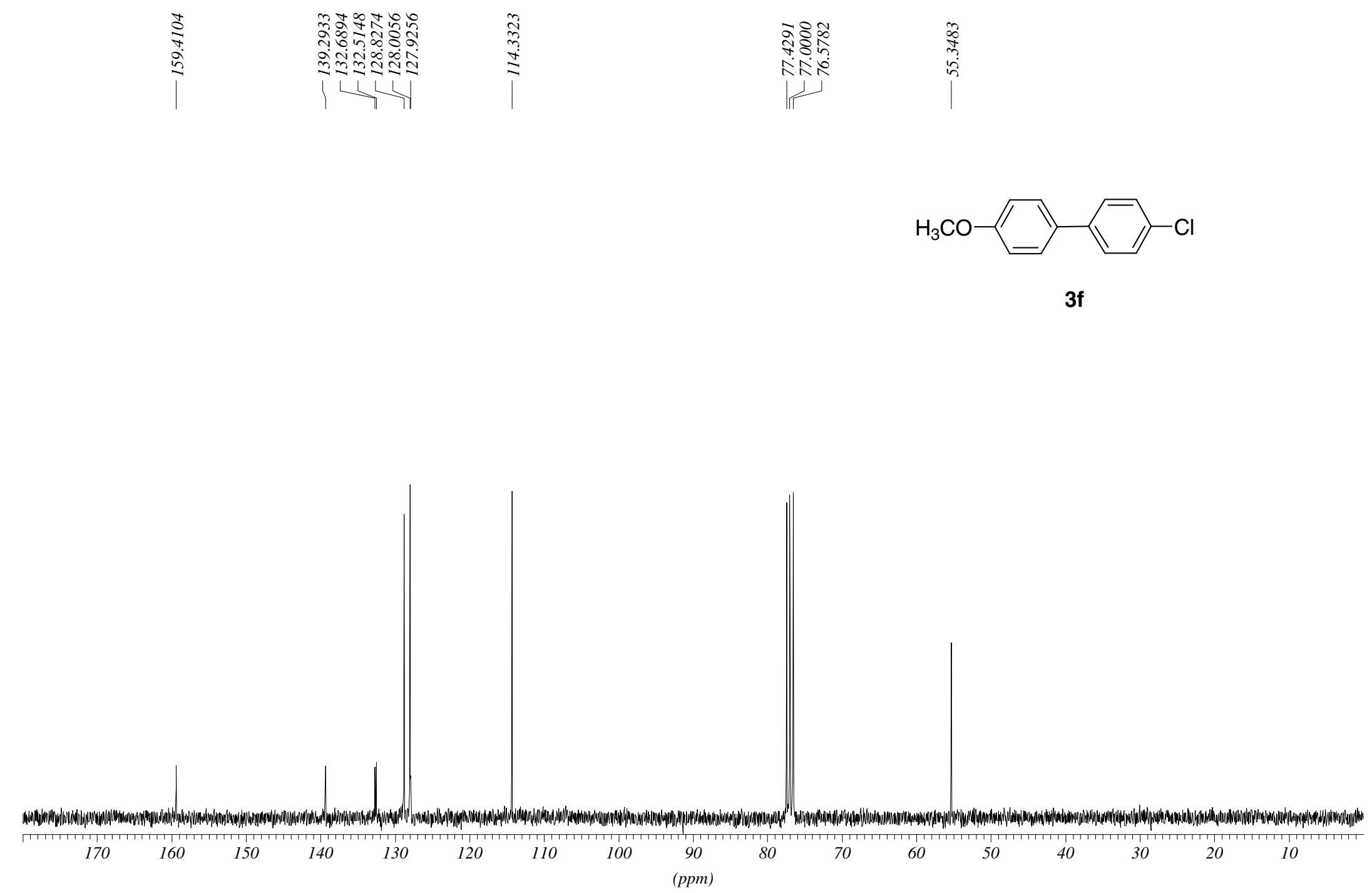


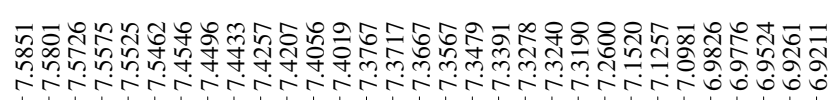

ता 1 III III $I 1$

$\left.\right|_{\substack{0 \\ 0}} ^{\substack{0 \\ 0}}$

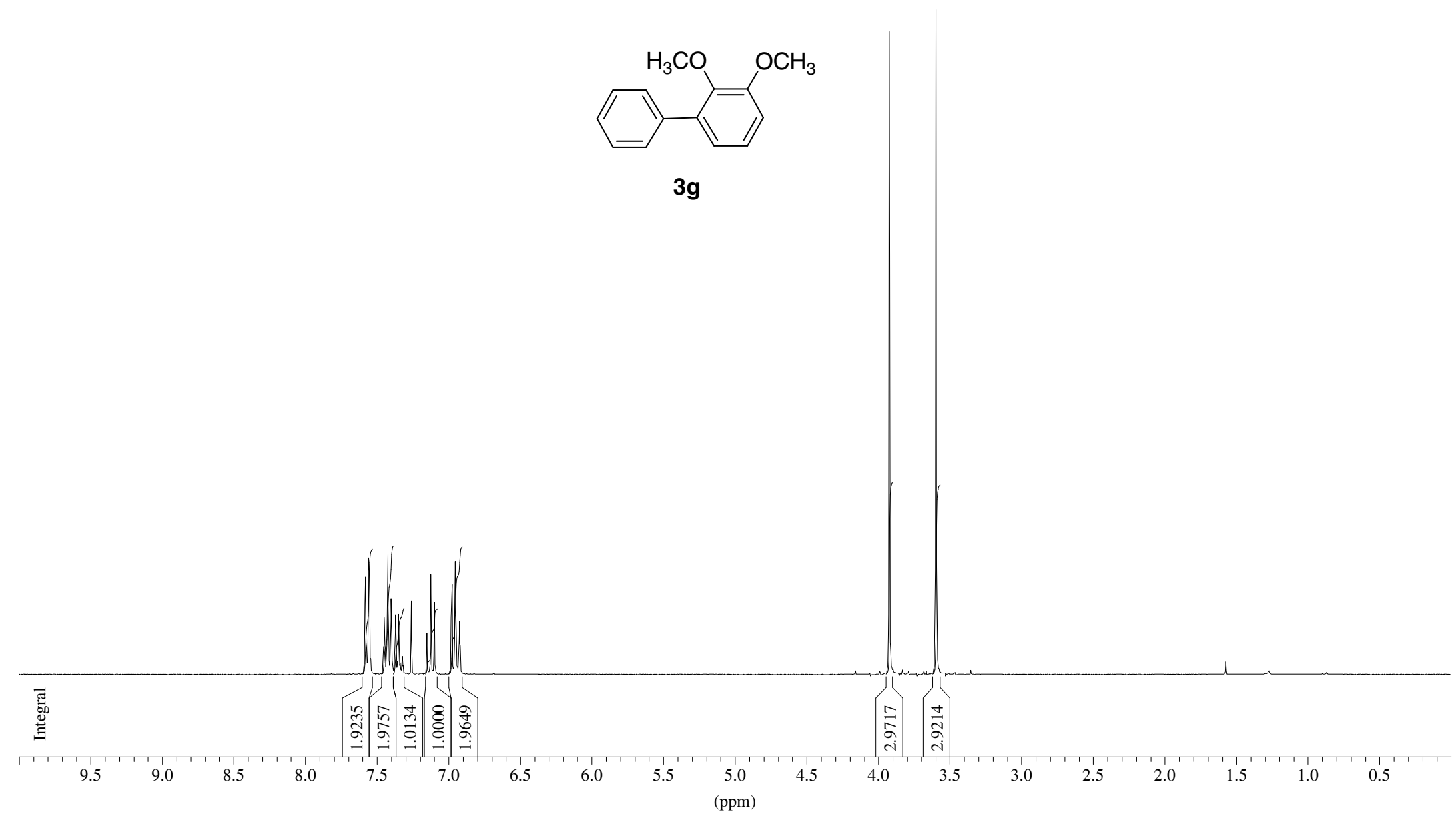




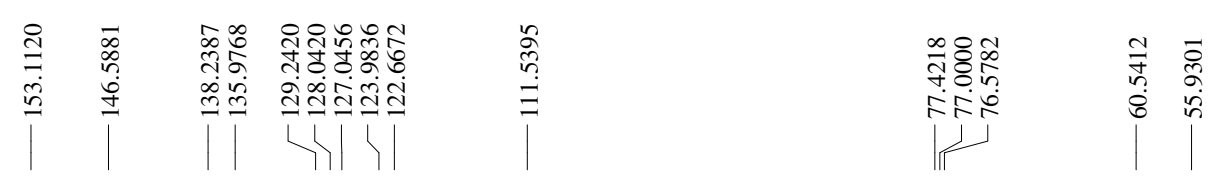

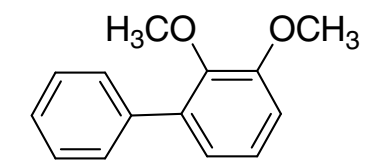

$3 g$

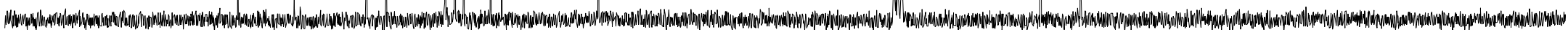

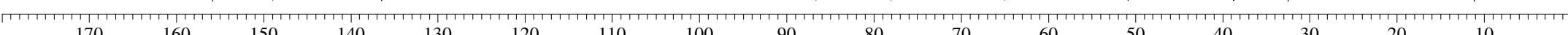




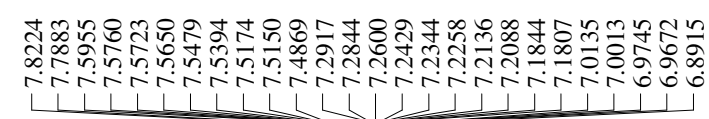

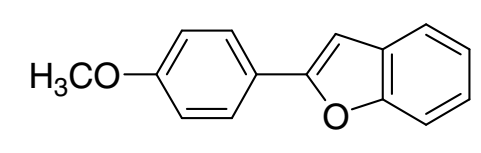

$3 h$

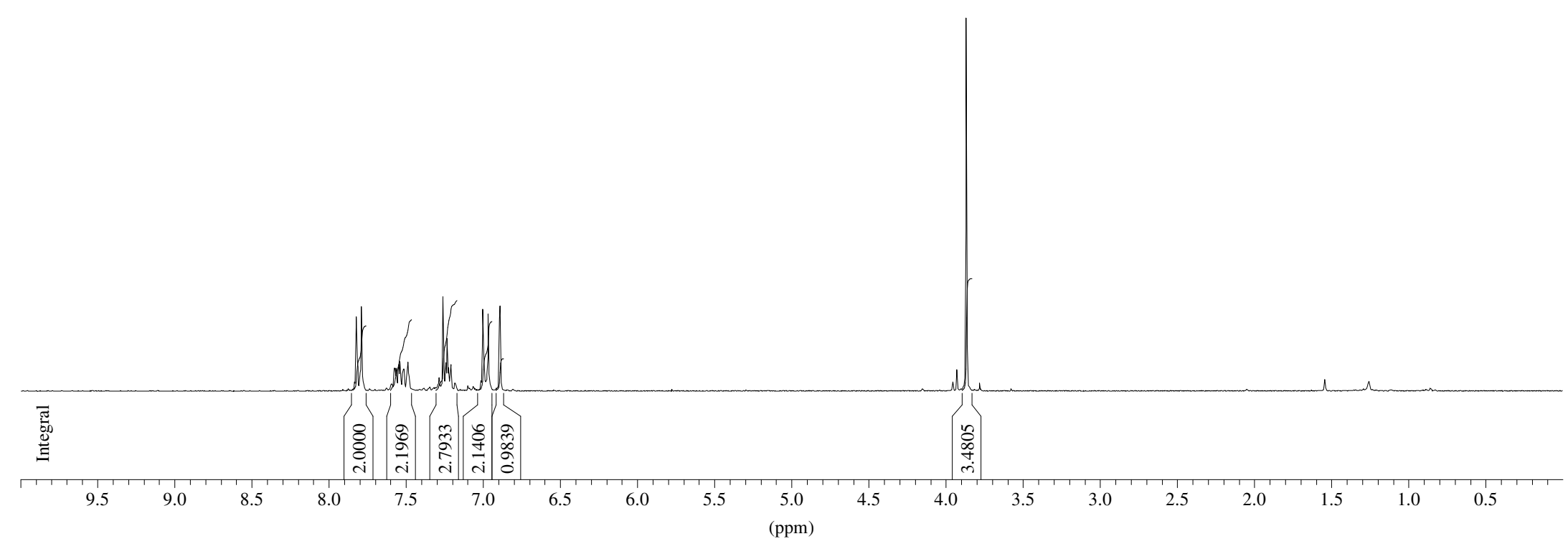




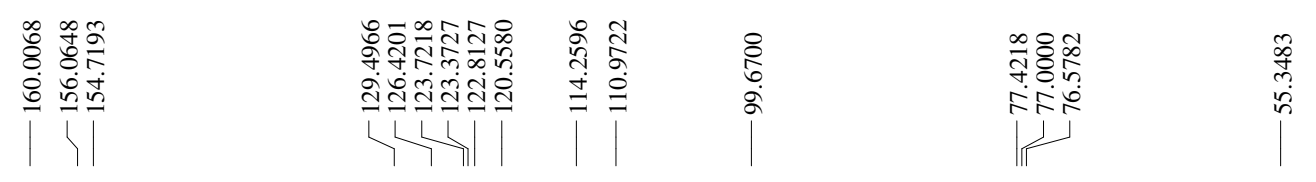

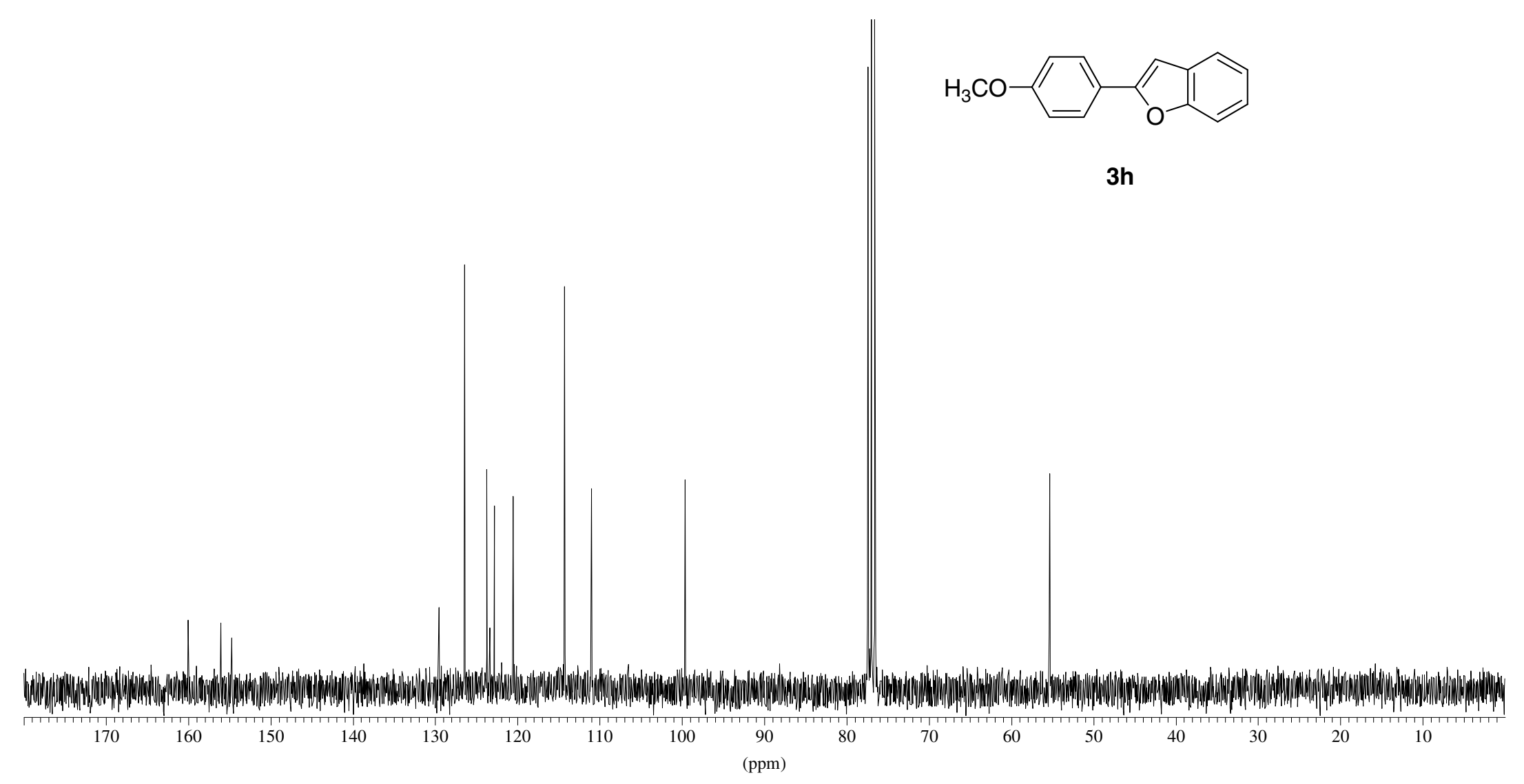




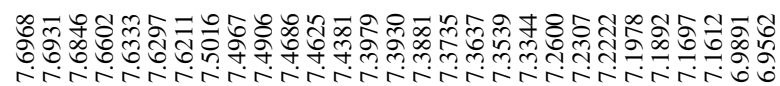
जाI II III IIIII

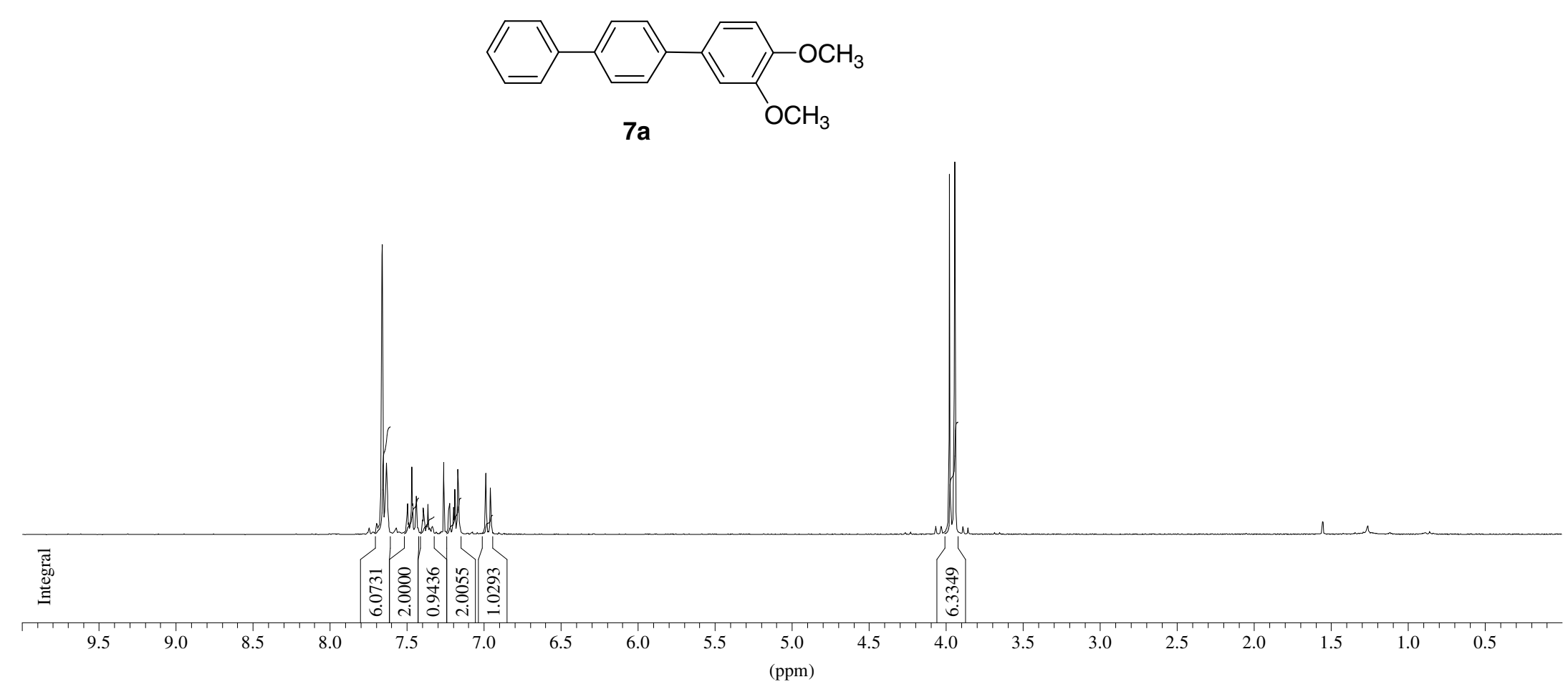




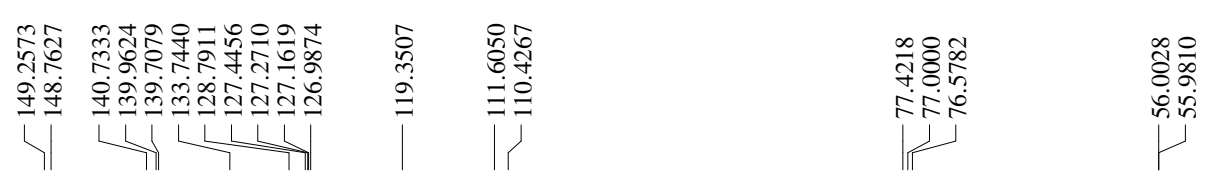
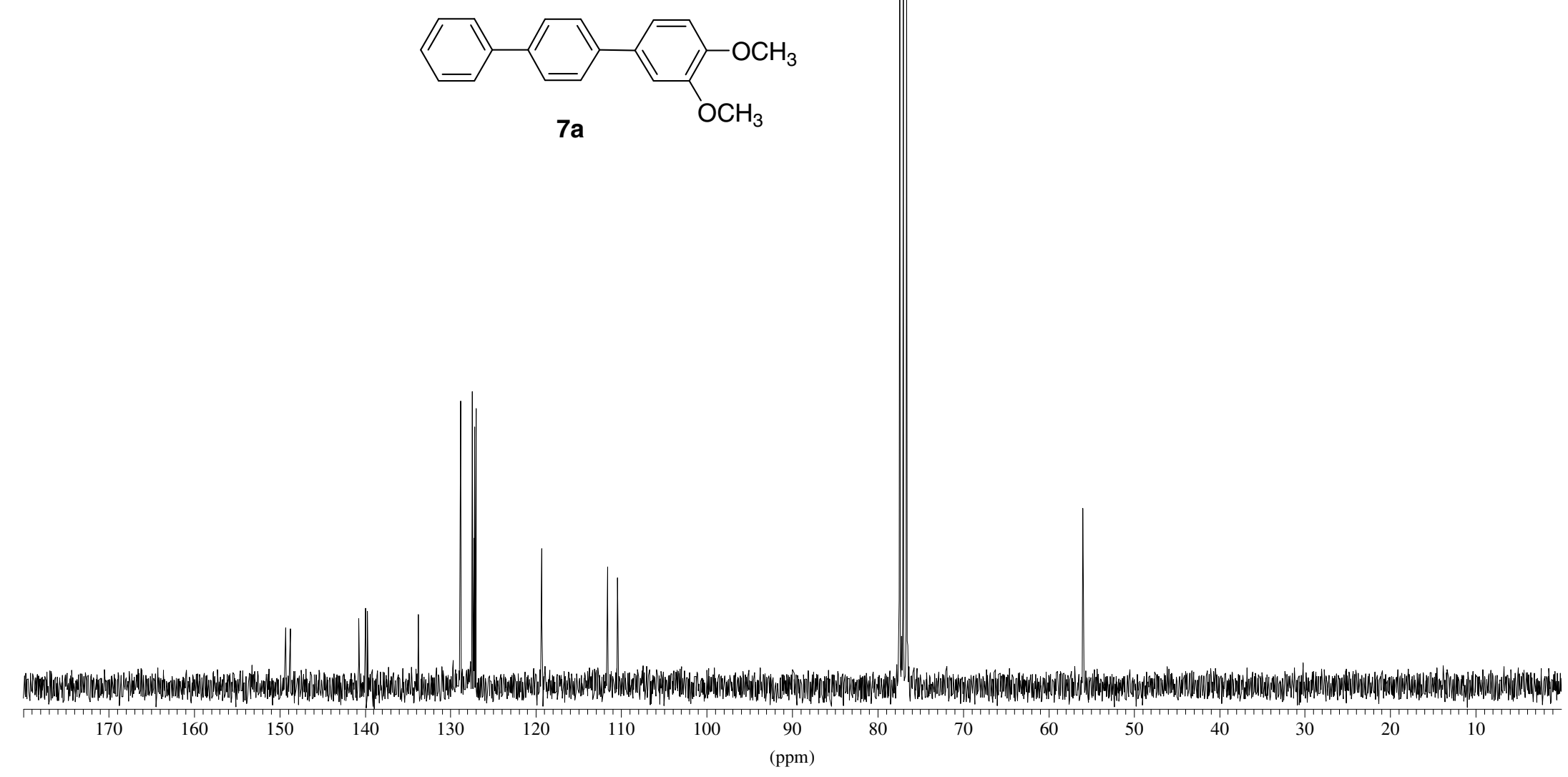


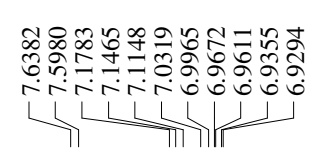

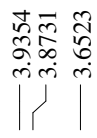
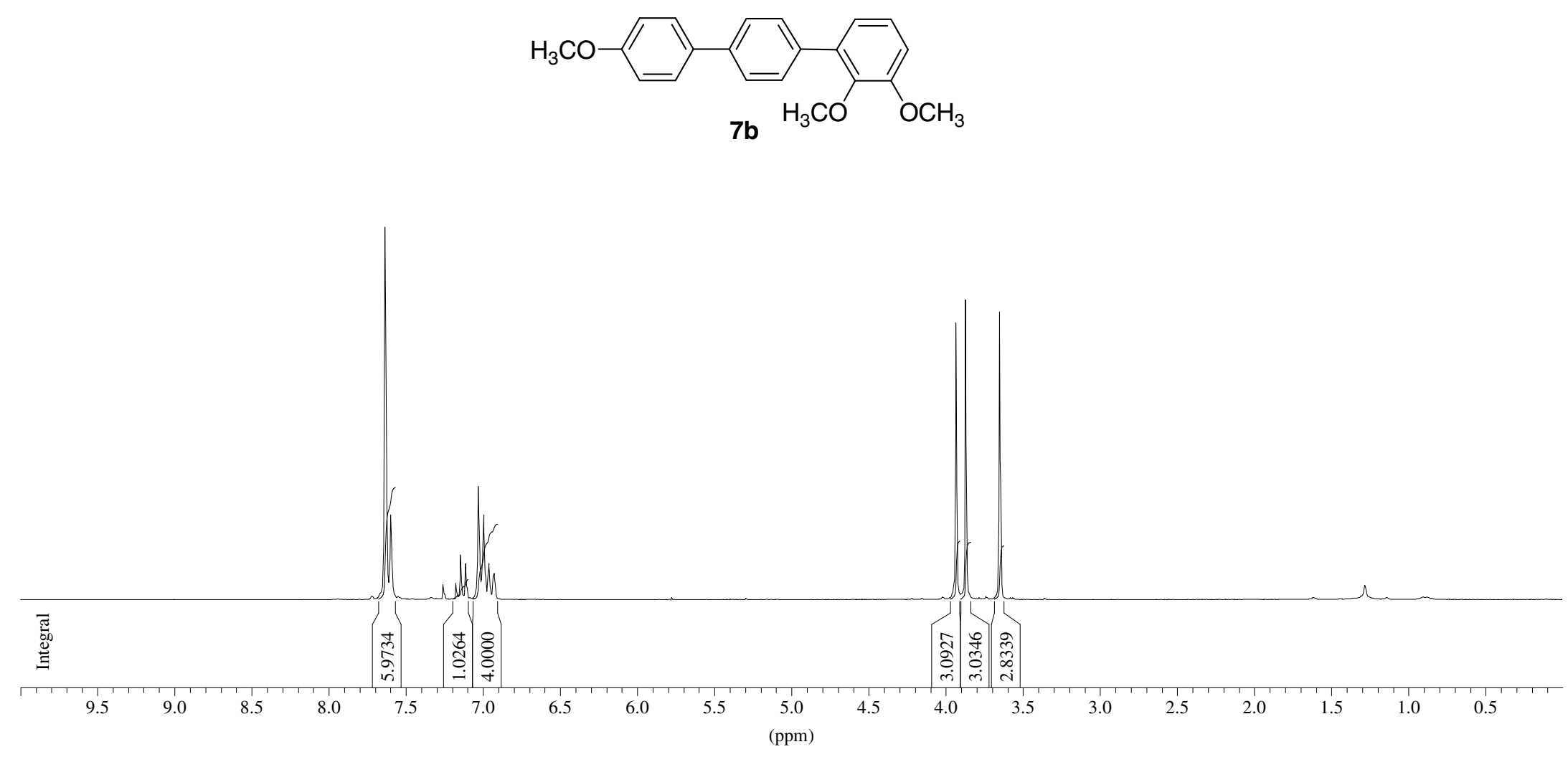


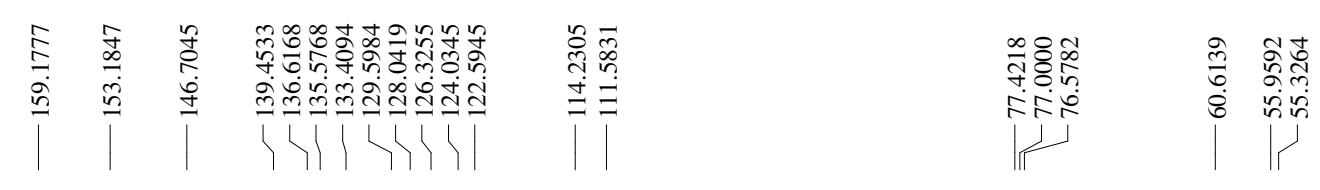

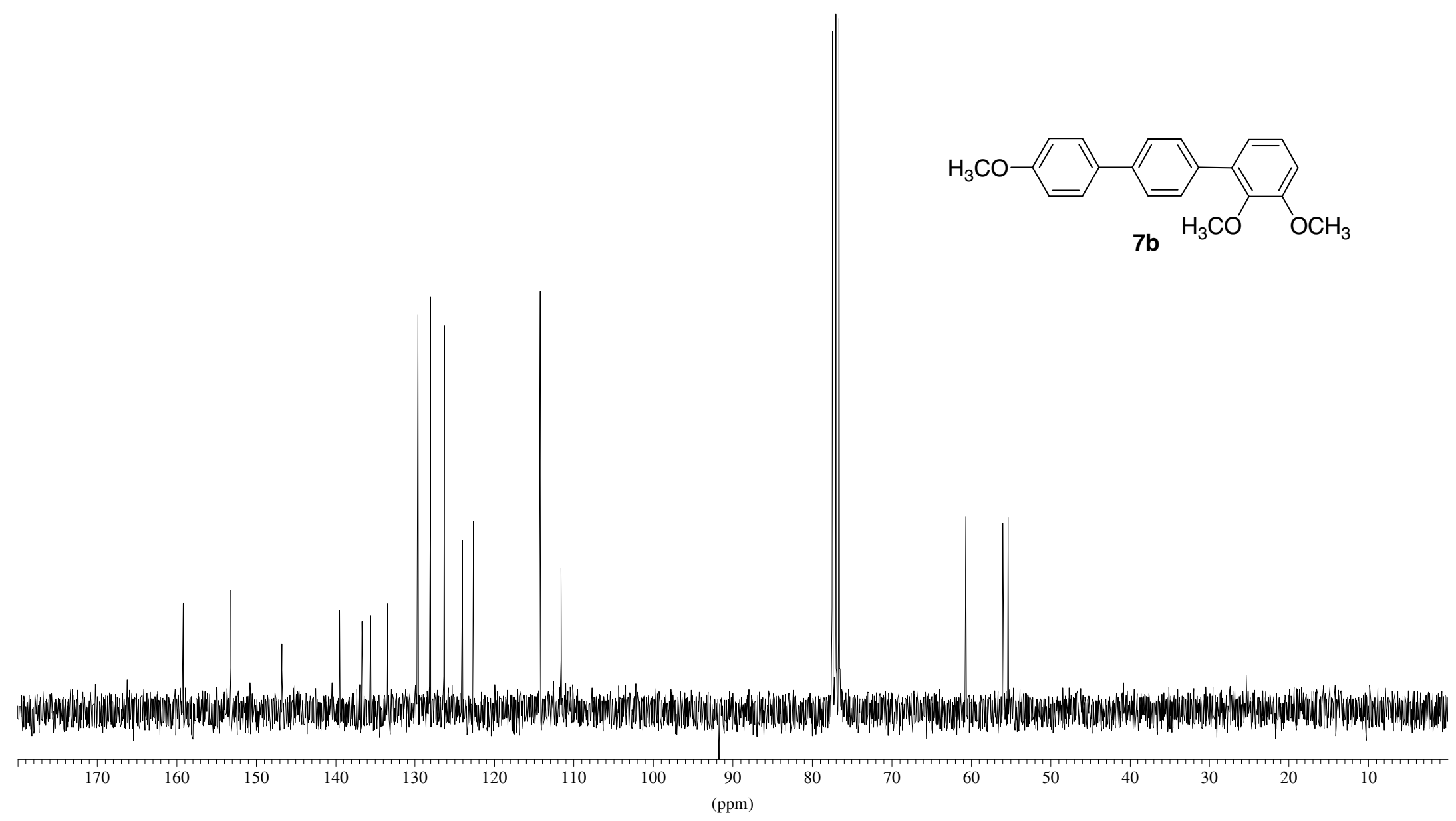


|
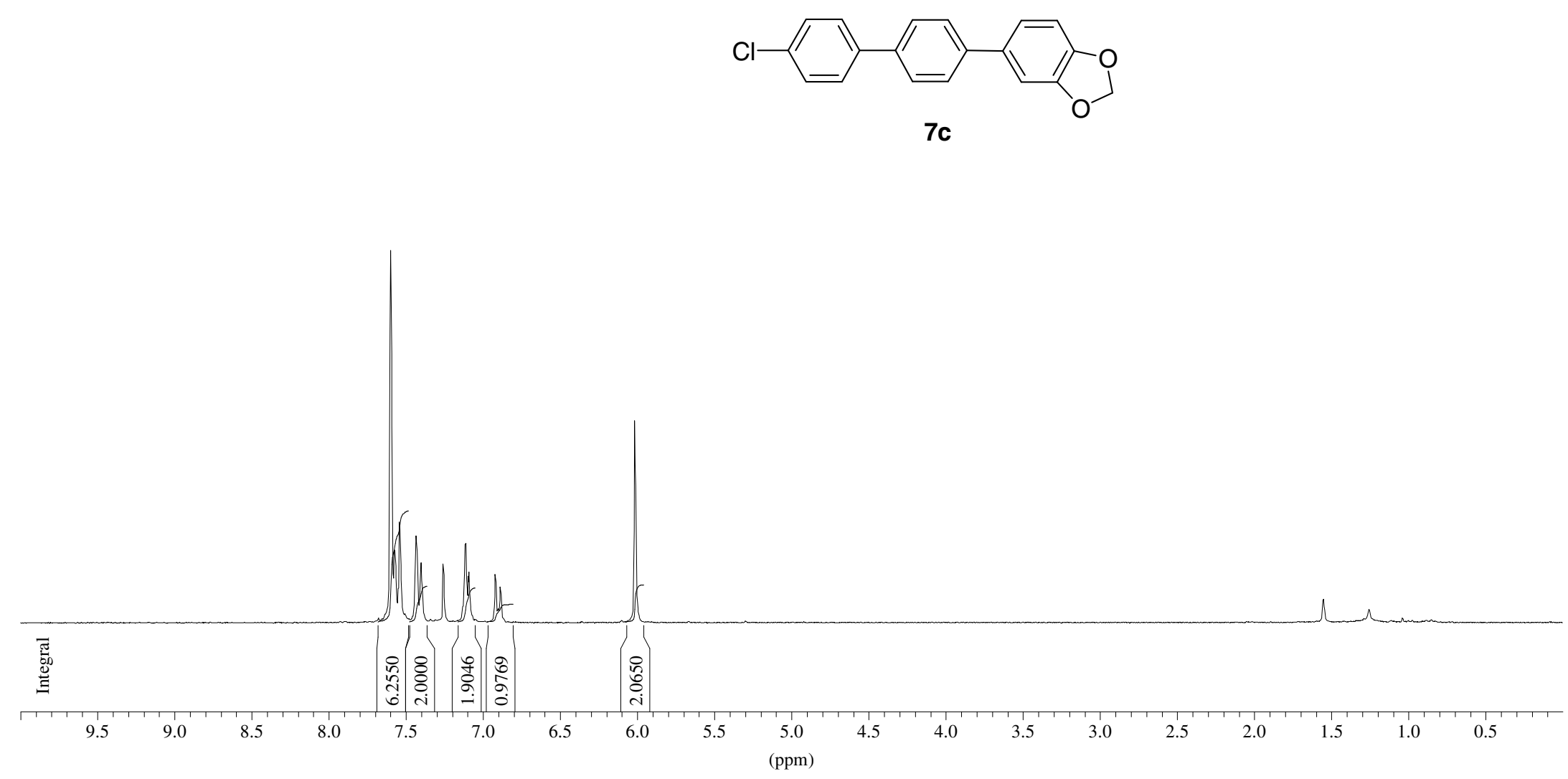


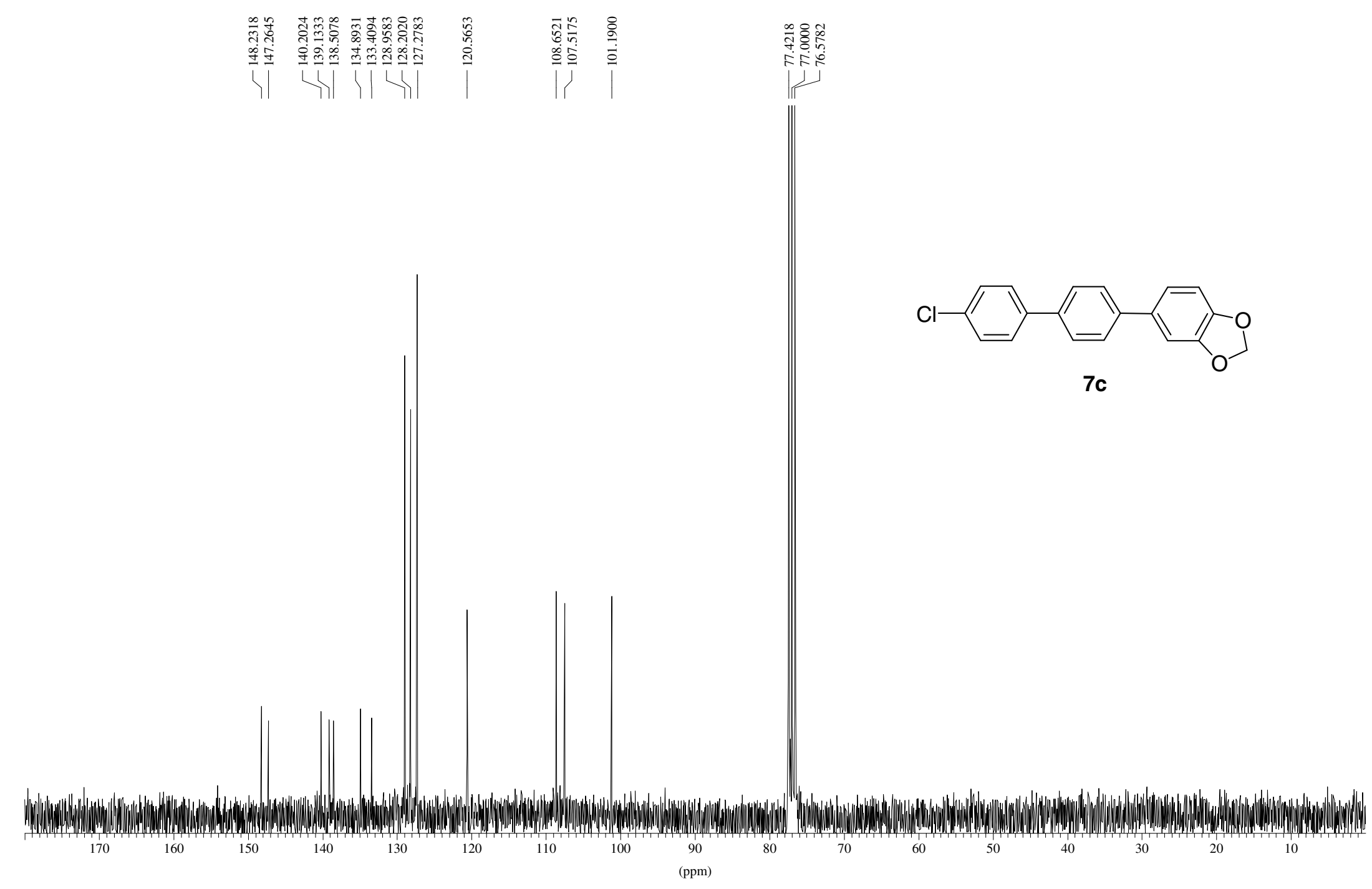




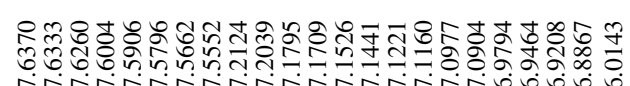

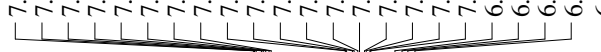
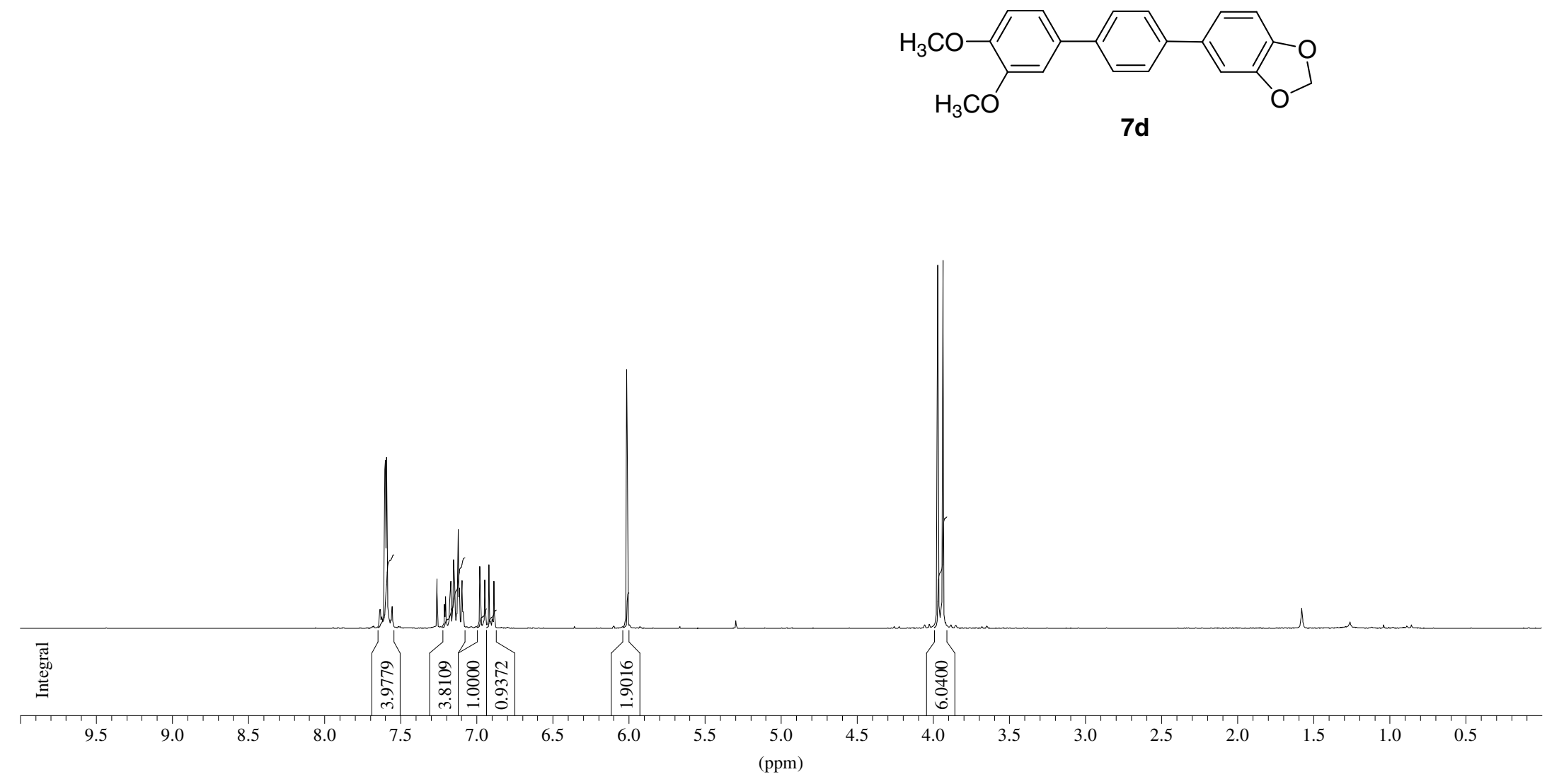


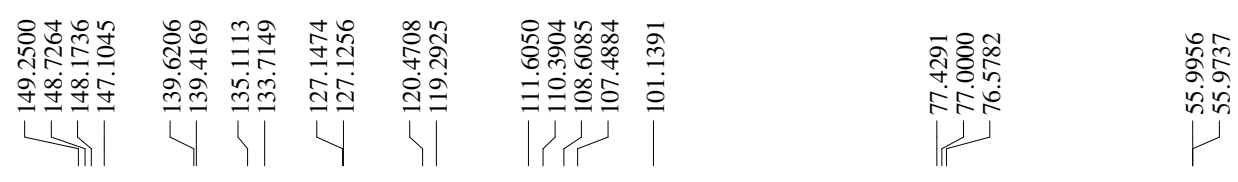

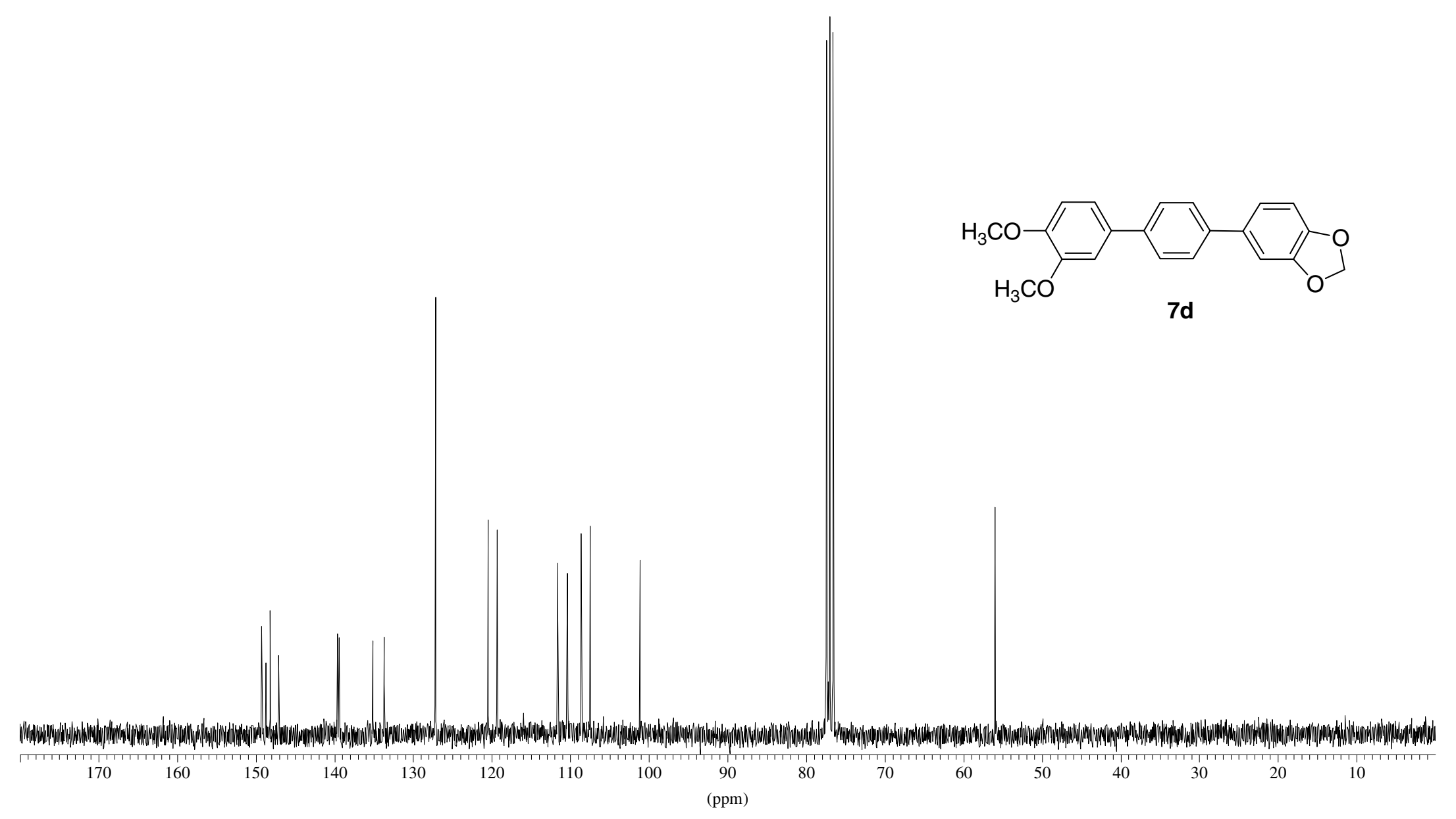




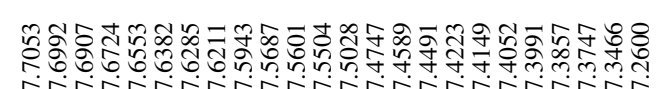

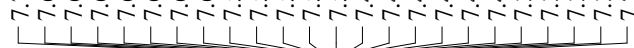

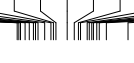

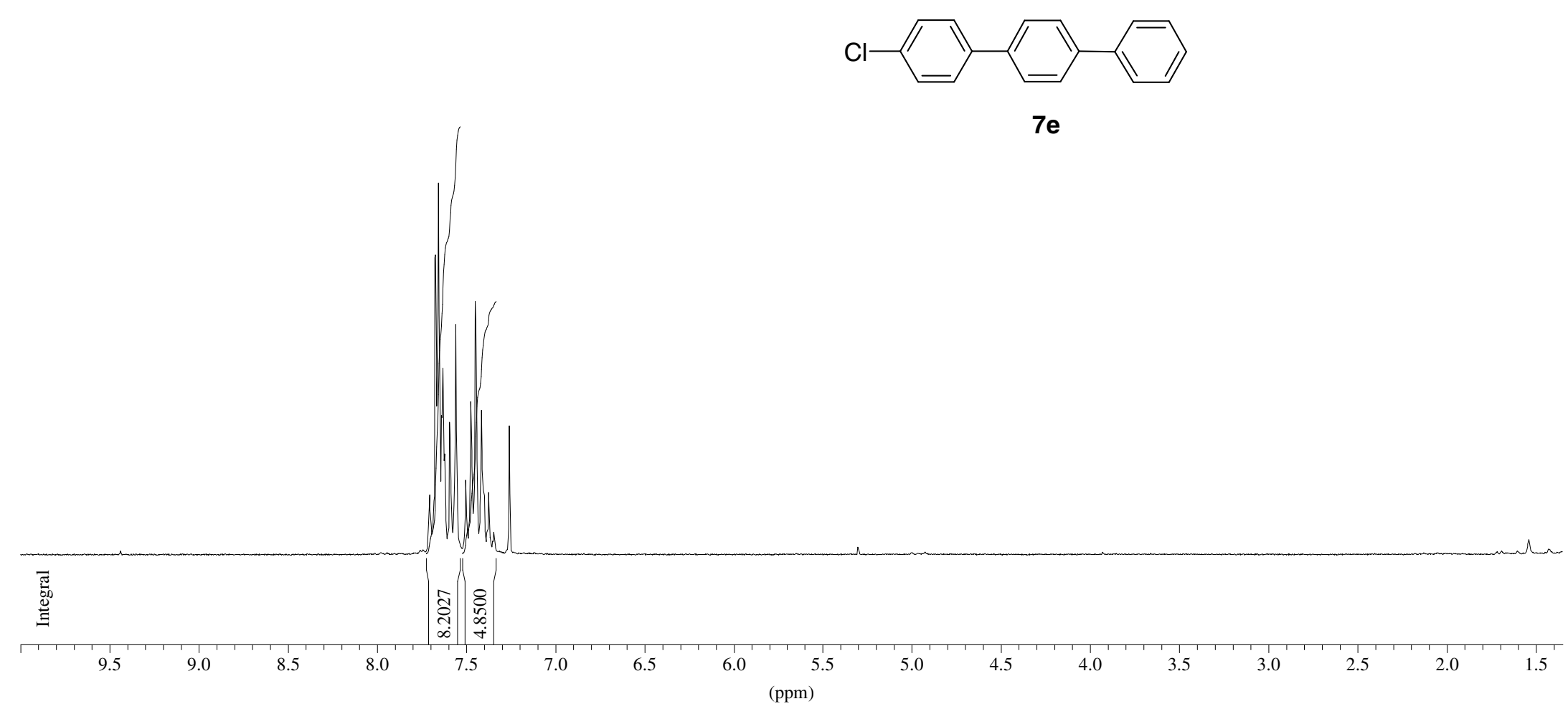




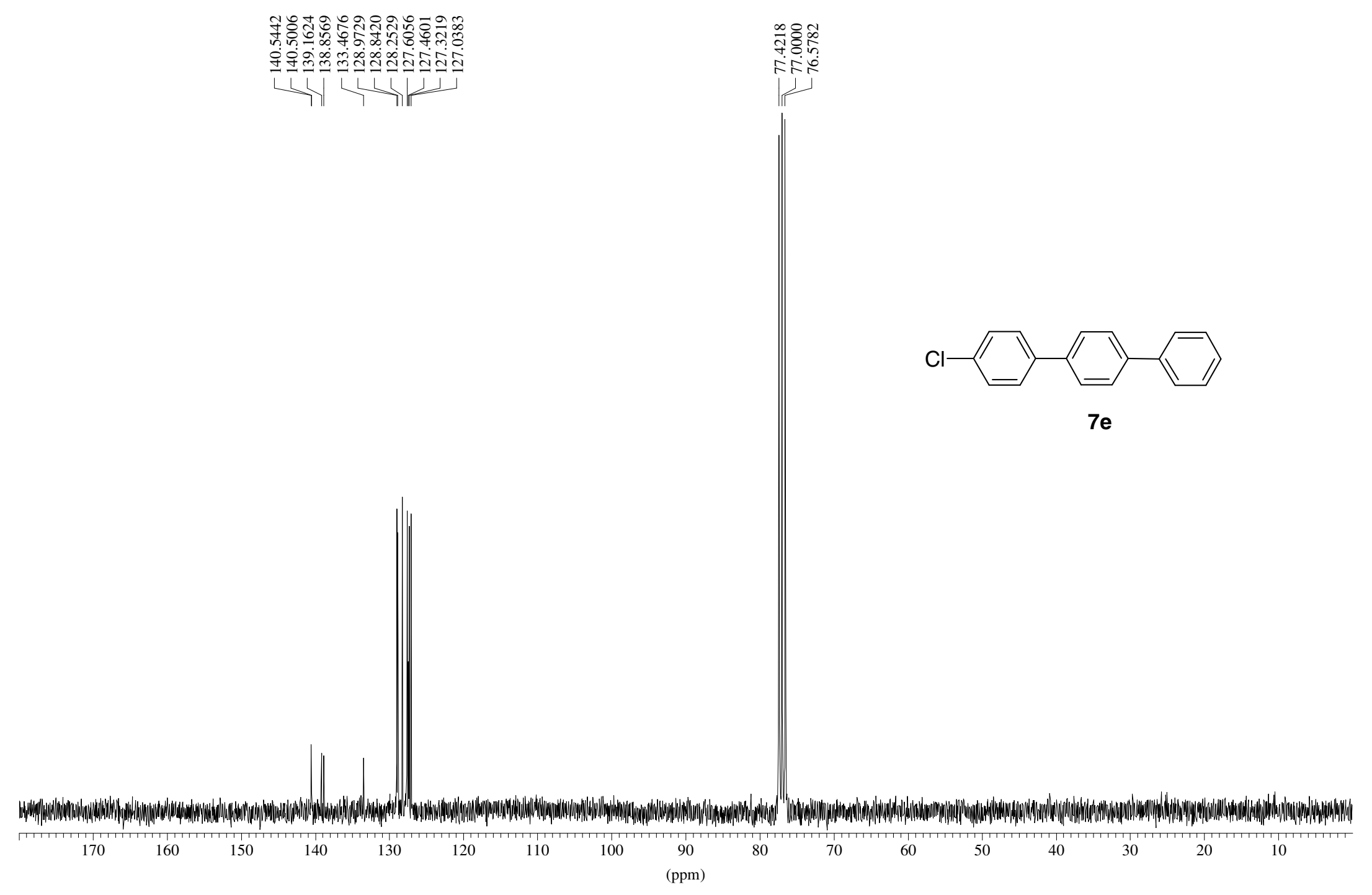

